\title{
Neighborhood walkability or third places? Determinants of social support and loneliness among older adults
}

Article

Accepted Version

Lee, J. H. and Tan, T. H. (2019) Neighborhood walkability or third places? Determinants of social support and loneliness among older adults. Journal of Planning Education and Research. ISSN 1552-6577 doi:

https://doi.org/10.1177/0739456x19870295 Available at https://centaur.reading.ac.uk/88110/

It is advisable to refer to the publisher's version if you intend to cite from the work. See Guidance on citing.

To link to this article DOI: http://dx.doi.org/10.1177/0739456x19870295

Publisher: Sage

All outputs in CentAUR are protected by Intellectual Property Rights law, including copyright law. Copyright and IPR is retained by the creators or other copyright holders. Terms and conditions for use of this material are defined in the End User Agreement.

www.reading.ac.uk/centaur 
Central Archive at the University of Reading

Reading's research outputs online 


\title{
Neighborhood Walkability or Third Places? Determinants of Social Support and Loneliness among Older Adults
}

\author{
Ji Hei Lee' $\mathbb{D}$ and Teck Hong $\operatorname{Tan}^{2}$
}

\begin{abstract}
In the context of creating age-friendly communities, this paper examines the effects of neighborhood walkability and third places on older adults' social connectedness. The subject was older adult homeowners aged sixty-five years and above in the context of American college towns. Partial least squares structural equation modeling was used, controlling personal abilities and sociodemographic factors. Third places positively influenced older adults' social support network, but it was not associated with loneliness. Objective and perceived neighborhood accessibility had no association with either social support network or loneliness in later life. Findings suggest that planners and developers should prioritize third places in designing for active living.
\end{abstract}

\section{Keywords}

active aging, aging in place, built environment, mental health, social health, well-being

\section{Introduction}

Creating age-friendly communities has been a key urban and national policy agenda item globally, due to a significantly increasing older adult population. In 2007, the World Health Organization first introduced the Age-Friendly Cities and Communities program to foster learning across the globe to create environments to support aging. In 2010, it initiated the Global Network of Age-Friendly Cities to formalize a structure of information exchange among cities and to promote awareness of providing infrastructure for the elderly. Among various policies and programs across the globe, the approaches for creating age-friendly communities can be found broadly in three dimensions: physical environment, social environment, and governance (Lui et al. 2009). This paper will focus on physical and social environment in pursuit of active living and healthy aging.

Elderly individuals have different personal characteristics and coping mechanisms for aging and there is no one perfect place for all (Golant 2015). However, two trends are salient among the baby boomer generation: aging in place and retiring in college towns. In the United States, nearly 90 percent of older adults prefer to "age in place," that is, continue to live in their current home and neighborhood, as opposed to relocating to an assisted-living environment (Farber et al. 2011; Federal Interagency Forum on Aging-Related Statistics 2016).

Another growing preference in the United States is retiring in college towns (Carle 2019; Hu et al. 2008). Relocation decisions on where to retire is significantly influenced by one's familiarity with another community (Cuba and
Longino 1991; Haas and Serow 1993) which is likely to be their former neighborhood or the city where they went to school (Hu et al. 2008). In addition, characteristics of college towns are very similar to the determinants of choosing a retirement location ( $\mathrm{Hu}$ et al. 2008), such as low cost of living, availability of quality housing, adequate health care facilities, community security, recreational opportunities, and cultural amenities (Hass and Serow 1993). The trend is evidenced by the significant increase of retirement community development on or near university campuses in the recent twenty years. Housing developers have been capitalizing on the resources and amenities of college towns for their senior housing developments. For the two decades, colleges and universities also have gradually involved in the development of retirement villages on or close to their campuses, so-called University-Based Retirement Communities (Carle 2006). There are about hundred locations with varying associations with universities in the United States (Carle 2019). The increasing number of older adults retiring to

Initial submission, April 2018; revised submissions, December 2018, July 2019; final acceptance, July 2019

'University of Reading Malaysia, Iskandar Puteri, Malaysia

${ }^{2}$ Xiamen University Malaysia, Sepang, Malaysia

Corresponding Author:

Ji Hei Lee, Henley Business School, University of Reading Malaysia, Persiaran Graduan, Kota Ilmu, Educity, Iskandar Puteri, Johor 79200, Malaysia.

Email: j.h.lee@reading.ac.uk 
college towns shows the growing popularity of college towns (Brooks 2018).

\section{Social Connectedness}

For better quality of life, older adults should have access to an enabling environment that assists them to remain physically active and socially connected. One of the key determinants of quality of life among the elderly is social connectedness. Social connectedness is defined as the amount and quality of social relationships (Jong-Gierveld, Tilburg, and Dykstra 2006). It has two dimensions: social support network (objective dimension) and loneliness or feeling of isolation (subjective dimension). Social support network is the network of care or help from others that a person can receive (Wang 2016). Loneliness, that is, feeling of isolation is a perceived "state in which an individual lacks a sense of belonging socially, lacks engagement with others, has a minimal number of social contacts, and are deficient in fulfilling and quality relationships" (Nicholson 2009). Although a person has a wide, strong social support network, he or she may feel isolated or friendless. Meanwhile, others may not feel isolated or lonely although they have a relatively narrow, weak social support network. Elderly individuals with strong social connectedness tend to have a lower level of mortality (Sabin 1993; Steinbach 1992). A lack of social support has been known as a major risk factor for older adults' health (House, Landis, and Umberson 1988). Feeling of isolation or loneliness is also correlated with mental illness, distress, dementia, suicide, and premature death (Fratiglioni et al. 2000; House, Robbins, and Metzner 1982; Lester and Yang 1992).

Risk factors for social isolation and loneliness are known to include being older, being single/widowed/divorced, recently relocating to a new area, being in poor health condition, not being a homeowner, being female, and having lived in a community for only a short period of time (Kobayashi et al. 2008). They also include living alone (Havens et al. 2004), having a significant life event such as the recent death of a spouse or a close friend (Wenger and Burholt 2004), and cognitive decline (Barnes et al. 2004). However, there is little empirical evidence on physical and social environmental factors of social connectedness among the elderly in various spatial contexts. To fill the gap, this paper aims to examine the effect of neighborhood walkability and third places on social support network and loneliness among older adults in the context of American college towns.

\section{Third Places and Social Connectedness}

Third places have been recognized as an important medium of being socially connected with friends and neighbors. A third place (Oldenburg and Brissett 1982) is a place to spend time with friends or neighbors outside the home. Third places are the social surroundings that are distinct from the two social environments of the home and the workplace, such as cafes, clubs, public libraries, or parks. Third place provides opportunities for informal social interaction (Oldenburg 1997). When there are opportunities for everyday informal face-to-face contact, casual social relationships are developed and maintained (Granovetter 1983). Casual social relationships or weak ties are important contributors to social support (Henning and Lieberg 1996). Although the relationships created at third places are weak, people receive social support from third-place relationships that corresponds to their perceived support deficits from family members or retirement (Rosenbaum et al. 2007). Particularly, in deprived neighborhoods, a third place functions as an important medium for social interaction among residents (Hickman 2013). Proximity to common meeting places and facilities is a significant factor in promoting casual interaction among residents (Alidoust, Bosman, and Holden 2018; Rogers et al. 2011). In regard to housing preference, accessibility to third places is also an important consideration when the elderly evaluate senior living options (Gibler and Taltavull 2010). In this sense, having a place to socialize outside the home may be potentially viewed as an important intervention strategy to promote older adults' social connectedness, which needs empirical validation in various settings. Despite some insights on the relevance of third places on older adults' social connectedness, one limitation still remains in the research design and method. Most empirical literature on third places did not include people who did not have third places as study subjects. The actual effect of third places on social connectedness can be validated only after including both groups, that is, users and nonusers.

\section{Neighborhood Walkability and Social Connectedness}

Neighborhood environment plays a significant role in supporting health and well-being in later life as it could increase the comfort, safety, and health of the elderly (Cisneros et al. 2012). A living environment with a high level of care helps to promote independence in later life. Older adults' health condition can be improved if the neighborhood environment provides opportunities for active living, socializing, and mutual support among residents (Sugiyama and Thompson 2007). From the perspective of senior housing preferences, the quality of neighborhood environment is one of the most important attributes. In later life, living in a neighborhood featuring a wide range of supportive systems could remove the threat and adverse consequence of loneliness and social isolation (Tang and Lee 2011).

Neighborhood characteristics in relation to older adults' social connectedness has been studied since the 1980s. In the early years, scholars focused on the impact of neighborhood safety and maintenance. They found a strong correlation between social interaction and factors such as crime rate, noise, and deterioration (Krause 1993). Since the rise 
Table I. Characteristics of the Study Area.

\begin{tabular}{|c|c|c|c|}
\hline & College Station & Bryan & USA \\
\hline Land area $\left(\mathrm{km}^{2}\right)$ & 128.5 & 115.3 & \\
\hline Population (2013) & 100,050 & 78,709 & \\
\hline Population (2017) & II 3,564 & 84,021 & \\
\hline Density (people/km²) (20I3) & 778.6 & 682.6 & \\
\hline Older adults age $65+$ years $(2013)$ & $4,702(4.7 \%)$ & $6,958(8.8 \%)$ & $13 \%$ \\
\hline \multicolumn{4}{|l|}{ Race $(2010)$} \\
\hline White alone & $77.3 \%$ & $43 \%$ & $63.7 \%$ \\
\hline Hispanic or Latino & $14.0 \%$ & $36 \%$ & $16.3 \%$ \\
\hline $\begin{array}{l}\text { Estimated median home value } \\
\text { (20II) }\end{array}$ & $\$ 178,300$ & $\$ 105,900$ & \\
\hline
\end{tabular}

Source: U.S. Census Bureau.

of the New Urbanism movement in the 1980s, much of the focus of research on social interaction has changed to neighborhood walkability (Wilkerson et al. 2012). The benefit of neighborhood walkability on social interaction is rooted in a rationale that attributes of a neighborhood associated with walking or pedestrian friendliness may encourage residents to spend more time walking in the neighborhood, and thus promote casual interaction and develop relationships among neighbors. Significant correlates of social capital and sense of community include exposure to nature (Kweon, Sullivan, and Wiley 1998), a pedestrian-oriented neighborhood design (Lund 2002), access to parks and retailers (Lund 2003), the number of walkable locations (Leyden 2003; Rogers et al. 2011), neighborhood safety from crime (Thompson and Krause 1998), and higher commercial floor-area ratio (Wood et al. 2010). Overall, in the context of American communities, neighborhood walkability seems to have some effects on social capital, sense of community, and neighborliness. However, findings seem inconsistent in different geographical contexts. For example, a study conducted in the suburbs of Perth, Australia, showed a contrasting result where the number of destinations within $800 \mathrm{~m}$ had a negative influence on social capital (Du Toit et al. 2007). In a study conducted in Japan (Hanibuchi et al. 2012), neighborhood walkability was not associated with social capital.

In the previous studies, social connectedness was measured at a neighborhood scale. The measures of social connectedness include social capital, sense of community, or neighborliness, which captures social connectedness "within a neighborhood." Older adults' social support network is not necessarily bound to a neighborhood. It is not tested yet whether meaningful social relationships occur within or beyond a neighborhood for older adults aging in place. Babyboomers seem to be more mobile and have more extended life-space boundaries than the past generations. Measuring social connectedness at the neighborhood level may not accurately represent older adults' actual social connectedness. It requires to be understood, encompassing the neighborhood and beyond. This paper also seeks to fill this gap.

We test how neighborhood walkability and third places influence older adults' social support network and loneliness, controlling personal abilities and sociodemographic variables. Research hypotheses are as follows: third places influence social support network (Hypothesis 1a [H1a]) and loneliness (Hypothesis $1 \mathrm{~b}[\mathrm{H} 1 \mathrm{~b}]$ ); objective neighborhood accessibility influences social support network (Hypothesis $2 \mathrm{a}[\mathrm{H} 2 \mathrm{a}]$ ) and loneliness (Hypothesis 2b [H2b]); perceived neighborhood accessibility influences social support network (Hypothesis 3a [H3a]) and loneliness (Hypothesis 3b [H3b]); neighborhood safety from crime influences social support network (Hypothesis 4a [H4a]) and loneliness (Hypothesis 4b [H4b]).

\section{Method}

\section{Study Area, Subjects, and Survey Method}

Despite the growing popularity of college towns as retirement communities, neighborhood walkability and third places have not been examined in such settings. This study chose two college towns as study areas: city of College Station and city of Bryan in Texas. They are characterized with the aforementioned attributes of college towns: a relatively low cost of living, an affordable range of housing prices, the availability of quality hospitals and health care facilities, and good access to recreational and educational opportunities. Table 1 describes the sociodemographic characteristics of the study area.

The typical types of housing in the United States are detached single-family houses, town houses or other row houses, and apartments/condos. The subject of this study is homeowners aged 65 years and above living in their own single-family homes. The recipient list of "over sixty-five homestead tax exemption in 2013" was obtained from the county tax office. The total number of individuals under the 
tax exemption category was 7,570, which accounted for 65 percent of total older adult population, 11,660, of two cities.

The Drop-off and Pick-up survey (DOPU) method was used for data collection. The DOPU technique is known as an effective means to reduce nonresponse bias through increased response rates (Allred and Ross-Davis 2011; Melevin et al. 1999). The typical response rate of the DOPU typically ranges from 33 to 79 percent across neighborhoods, whereas the response rate of mail surveys ranges from 10 to 15 percent (Jackson-Smith et al. 2016).

The sample size was determined by applying the probability sampling formula for a simple random sample (population size $=7,570$, confidence level $95 \%$, margin of error $=5 \%$ ) as follows: $\{(7,570)(0.5)(0.5)\} /\left\{(7,570-1)(0.05 / 1.96)^{2}+\right.$ $(0.5)(0.5)\}=366$. To reach our targeted responses $(n=$ 366 ), we took a conservative approach by applying the lowest response rate of the DOPU, that is, 33 percent. After applying the lowest response rate, the minimum number of potential participants to be reached was $1,109(=366 / 0.33)$, which is equivalent to the 14.6 percent of the total population. Hence, we decided to reach 15 percent of the population $(=1,150)$. From the list of addresses, 15 percent $(=1,150)$ of the total population $(=7,570)$ was selected by a simple random sampling method. The survey data were collected by one surveyor between 9:00 a.m. and 6:00 p.m. from late March to May in 2014. Although 363 agreed to receive a survey, 320 older adults in total entered the survey questionnaire, resulting in 305 useable completed surveys.

\section{Measures}

Table 2 describes the variables. Existing, validated scales were adopted for most of the constructs. As there was no established scale to measure the use of third places, we developed a three-item scale. We operationalized a third place as "a place outside of work or home visited at least once a week to socialize," which reflects the essential elements of third places in previous literature: (1) regular, frequent use of the place outside work and home and (2) a place where informal socializing may happen (Oldenburg 1997; Oldenburg and Brissett 1982).

Access to amenities was measured by both objective and perceived scales. The objective scale that we selected is the Walk Score ranging from 0 to 10 which is a publicly available web-based tool to evaluate the walkability of an address being examined (see http://www.walkscore.com). It calculates the walking distance to nine amenity categories (i.e., grocery, restaurants, shopping, coffee, banks, parks, schools, books, and entertainment) through the distance-decay function, as considering weights and counts of that amenity; then, the score can be deducted as a penalty for having poor pedestrian friendliness such as long blocks or low intersection density (Walk Score 2011).

To control unmeasured heterogeneity in two cities, a binary variable called City was included in the model.

\section{Analytic Strategy}

The partial least squares structural equation modeling (PLSSEM) was used for statistical analysis with an application of SmartPLS 3.0. Although parameter estimation biases are inherent in regression analysis, the structural equation modeling approach makes it possible to study the measurement errors of the observed variables, thus ensuring a more rigorous analysis (Gefen, Straub, and Boudreau 2000). PLSSEM is insensitive to small sample sizes and does not have distributional assumptions (Hair et al. 2011; Reinartz, Haenlein, and Henseler 2009). Furthermore, the issues of identification and convergence caused by single-item variables are not a problem in the PLS-SEM (Garson 2016). Hence, the PLS-SEM was deemed to be most appropriate for our sample and variables.

\section{Results}

\section{Sample Characteristics and Their Use of Third Places}

Table 3 shows the characteristics of participants. The number of people who had a third place was 163 , which accounts for 55 percent of participants. The 45 percent of participants did not have any third place. The number of third places ranged from 0 to 10 . The average number of third places an individual had was one place $(M=1.3 ; S D=1.6$; Minimum $=$ 0 ; Maximum $=10$ ). The total trip frequency to third places was two times per week.

Life-space mobility measures participants' spatial boundary of daily activities, frequency of trips, and physical independence. The independence measure of mobility at a neighborhood level shows that people with complete independence accounts for 91 percent, those who need equipment only 5 percent, and those who need personal assistance 4 percent.

Third places were categorized by the Land-Based Classification Standards (LBCS), a land-use coding system for local, regional, and state land-use planning (American Planning Association 1999). Each place was ranked by the total number of users (Table 4).

\section{Measurement Model}

Our reflective measurement model was examined in terms of item reliability, internal consistency, convergent validity, and discriminant validity. First, all factor loadings were greater than 0.7 and significant $(p<.001)$, which ensures indicator reliability (Bagozzi and Yi 1988).

Second, to examine the internal consistency within a construct, this study used the composite reliability (CR). It is a more accurate measure of internal consistency than Cronbach's alpha because Cronbach's alpha does not consider the weights of the indicators' individual loadings. In a 
Table 2. Variables and Coding Scheme.

\begin{tabular}{|c|c|c|c|}
\hline & Scale/source & Items & Coding scheme \\
\hline \multicolumn{4}{|l|}{ Dependent variables } \\
\hline Social support network & $\begin{array}{l}\text { Friendship Scale } \\
\text { (Hawthorne 2008) }\end{array}$ & $\begin{array}{l}\text { cl. It is easy for me to relate to others. } \\
\text { c2. I have someone to share my feelings } \\
\text { with. } \\
\text { c3. I found it easy to get in touch with } \\
\text { others when I needed to. }\end{array}$ & $\begin{array}{l}\text { Almost always }=4 \text {, Most of the } \\
\text { time }=3 \text {, About half the time } \\
=2 \text {, Occasionally }=1 \text {, Not at } \\
\text { all }=0\end{array}$ \\
\hline Loneliness & & $\begin{array}{l}\text { c4. I feel isolated from other people. } \\
\text { c5. When with other people, I feel } \\
\text { separate from them. } \\
\text { c6. I feel alone and friendless. }\end{array}$ & $\begin{array}{l}\text { Almost always }=4 \text {, Most of the } \\
\text { time }=3 \text {, About half the time } \\
=2 \text {, Occasionally }=1 \text {, Not at } \\
\text { all }=0\end{array}$ \\
\hline \multicolumn{4}{|l|}{ Independent variables } \\
\hline $\begin{array}{l}\text { Objective neighborhood } \\
\text { accessibility }\end{array}$ & Walk Score (Walkscore.con & n 2015) & \\
\hline $\begin{array}{l}\text { Perceived neighborhood } \\
\text { accessibility }\end{array}$ & $\begin{array}{l}\text { Neighborhood } \\
\text { Environment Walkability } \\
\text { Scale (Cerin et al. 2006) }\end{array}$ & $\begin{array}{l}\text { al. Stores are within easy walking } \\
\text { distance. } \\
\text { a2. There are many places to go within } \\
\text { easy walking distance of my home. } \\
\text { a3. It is easy to walk to a transit stop } \\
\text { from my home. }\end{array}$ & $\begin{array}{l}\text { Strongly agree }=4 \text {, Somewhat } \\
\text { agree }=3 \text {, Somewhat disagree }= \\
2 \text {, Strongly disagree }=1\end{array}$ \\
\hline Safety from crime & & $\begin{array}{l}\text { crl. There is a high crime rate in my } \\
\text { neighborhood. } \\
\text { cr2. The crime rate is my neighborhood } \\
\text { makes it unsafe to go on walks during } \\
\text { the day. } \\
\text { cr3. The crime rate in my neighborhood } \\
\text { makes it unsafe to go on walks at night. }\end{array}$ & $\begin{array}{l}\text { Strongly agree }=4 \text {, Somewhat } \\
\text { agree }=3 \text {, Somewhat disagree }= \\
2 \text {, Strongly disagree }=1\end{array}$ \\
\hline Third place & & $\begin{array}{l}\text { pla. Do you have a place to socialize that } \\
\text { you visit regularly at least once a week? } \\
\text { num. How many places to socialize do } \\
\text { you have? } \\
\text { fre. How many times do you go there } \\
\text { per week? }\end{array}$ & Yes $=\mathrm{I}, \mathrm{No}_{\mathrm{o}}=0$ \\
\hline \multicolumn{4}{|l|}{ Control variables: } \\
\hline Age & & In what year were you born? & Converted into age \\
\hline Female & & What is your gender? & Female $=\mathrm{I}$, Male $=0$ \\
\hline Married & & What is your marital status? & $\begin{array}{l}\text { Now married }=1 \text {, Others }=0 \\
\text { (widowed, divorced, separated, } \\
\text { or never married) }\end{array}$ \\
\hline Living alone & & Do you live alone? & $\mathrm{Yes}=\mathrm{I}, \mathrm{No}=0$ \\
\hline Education & & $\begin{array}{l}\text { What is the highest grade or level of } \\
\text { school you have completed? }\end{array}$ & $\begin{array}{l}\text { Never attended school }(=1) \text {, } \\
\text { Grades I through II }(=2) \text {, } \\
\text { High school graduate }(=3) \text {, } \\
\text { Some college or technical school } \\
(=4) \text {, College graduate }(=5), \\
\text { Graduate school or more }(=6)\end{array}$ \\
\hline Home property value & & $\begin{array}{l}\text { Appraised home property value } \\
\text { (\$ in thousands) }\end{array}$ & \\
\hline City & & & $\begin{array}{l}\text { City of College Station = 0, City } \\
\text { of Bryan }=1\end{array}$ \\
\hline Significant life event & & $\begin{array}{l}\text { In the past three years, which of the } \\
\text { following major life events have taken } \\
\text { place in your life? }\end{array}$ & $\begin{array}{l}\text { None }=0, \text { Yes }=1 \text { (death of } \\
\text { close family member, death of } \\
\text { close friend, personal injury or } \\
\text { illness, retirement, or change in } \\
\text { residence) }\end{array}$ \\
\hline
\end{tabular}


Table 2. (continued)

\begin{tabular}{|c|c|c|c|}
\hline & Scale/source & Items & Coding scheme \\
\hline Self-efficacy & $\begin{array}{l}\text { General Self-Efficacy } \\
\text { Scale (Schwarzer and } \\
\text { Jerusalem 1995) }\end{array}$ & $\begin{array}{l}\text { sel. Thanks to my resourcefulness, } \\
\text { I know how to handle unforeseen } \\
\text { situations. } \\
\text { se2. I can solve most problems if I invest } \\
\text { the necessary effort. } \\
\text { se3. When I am confronted with a } \\
\text { problem, I can usually find several } \\
\text { solutions. } \\
\text { se4. If I am in trouble, I can usually think } \\
\text { of a solution. } \\
\text { se5. I can usually handle whatever comes } \\
\text { my way. }\end{array}$ & $\begin{array}{l}\text { Mostly true }=4 \text {, Moderately true } \\
=3 \text {, Hardly true }=2 \text {, Not at all } \\
\text { true }=1\end{array}$ \\
\hline Mobility frequency & $\begin{array}{l}\text { The University of } \\
\text { Alabama at Birmingham } \\
\text { Study of Aging Life- } \\
\text { Space Assessment (Peel } \\
\text { et al. 2005) }\end{array}$ & $\begin{array}{l}\text { mfl. During the past four weeks, how } \\
\text { often did you go to places in your } \\
\text { neighborhood, other than your own } \\
\text { yard or apartment building? } \\
\text { mf2. During the past four weeks, how } \\
\text { often did you go to places outside your } \\
\text { neighborhood, but within your town? }\end{array}$ & $\begin{array}{l}\text { Less than one time per week }(=1) \text {, } \\
\text { Less than one to three times per } \\
\text { week }(=2) \text {, Less than four to six } \\
\text { times per week }(=3) \text {, Daily }(=4)\end{array}$ \\
\hline Mobility independence & & $\begin{array}{l}\text { mil. During the past four weeks, when } \\
\text { you go to an area outside your home } \\
\text { (such as your porch, deck, patio, } \\
\text { garage or driveway), did you use aids } \\
\text { or equipment? Did you need help from } \\
\text { another person? } \\
\text { mi2. During the past four weeks, when } \\
\text { you go to places in your neighborhood, } \\
\text { other than your own yard or apartment } \\
\text { building, did you use aids or equipment? } \\
\text { Did you need help from another } \\
\text { person? }\end{array}$ & $\begin{array}{l}\text { No equipment or personal } \\
\text { assistance }=2 \text {, Equipment only } \\
=1.5, \text { Personal assistance }=1\end{array}$ \\
\hline
\end{tabular}

Table 3. Characteristics of Participants.

\begin{tabular}{lc}
\hline Characteristics & $N(\%)$ \\
\hline Age (years) & Mean age $=76(S D=6.7)$ \\
$65-74$ & $147(49.3)$ \\
$75-84$ & $114(38.3)$ \\
$85+$ & $37(12.4)$ \\
Gender & \\
Female & $162(53.8)$ \\
Male & $141(46.5)$ \\
Race & \\
White & $275(90.7)$ \\
Nonwhite & $28(9.2)$ \\
Married & \\
Now married & $227(74.4)$ \\
Widowed & $58(19.0)$ \\
Divorced & $16(5.3)$ \\
Separated & $1(0.3)$ \\
Never married & $3(1.0)$ \\
Living alone & \\
Living with someone & $249(82.5)$ \\
Living alone & $53(17.6)$ \\
\hline
\end{tabular}


Table 3. (continued)

\begin{tabular}{|c|c|c|}
\hline Characteristics & \multicolumn{2}{|c|}{$N(\%)$} \\
\hline \multicolumn{3}{|l|}{ Education } \\
\hline Zero year to high school graduate & \multicolumn{2}{|c|}{$64(21.1)$} \\
\hline College graduate & \multicolumn{2}{|c|}{$138(45.4)$} \\
\hline Graduate school or more & \multicolumn{2}{|c|}{$102(33.6)$} \\
\hline Home property appraised value $(\$)$ & \multicolumn{2}{|c|}{$185,292($ Minimum $=62,890$, Maximum $=760,250)$} \\
\hline \multicolumn{3}{|l|}{ City } \\
\hline Bryan & \multicolumn{2}{|c|}{$168(55.1)$} \\
\hline College Station & \multicolumn{2}{|c|}{137 (44.9) } \\
\hline Walk Score & \multicolumn{2}{|c|}{$M=28(S D=17.3$, Minimum $=0$, Maximum $=66)$} \\
\hline \multicolumn{3}{|l|}{ Significant life events } \\
\hline Yes & \multicolumn{2}{|c|}{$25 I(82.3)$} \\
\hline \multirow[t]{2}{*}{ No } & \multicolumn{2}{|c|}{$54(17.7)$} \\
\hline & Beyond home and within neighborhood & Beyond neighborhood and within town \\
\hline \multicolumn{3}{|l|}{ Mobility independence } \\
\hline Personal assistance & II (3.9) & $13(4.4)$ \\
\hline Equipment only & $14(5.0)$ & $20(6.8)$ \\
\hline No help needed & $256(91.1)$ & $261(88.8)$ \\
\hline \multicolumn{3}{|l|}{ Mobility frequency } \\
\hline Less than one time per week & $37(13.8)$ & $13(4.4)$ \\
\hline One to three times per week & $70(26.0)$ & $67(22.9)$ \\
\hline Four to six times per week & $55(20.5)$ & $\mid 20(4 \mid .0)$ \\
\hline Daily & $107(39.8)$ & $93(31.7)$ \\
\hline
\end{tabular}

Table 4. Older Adults' Use of Third Places.

\begin{tabular}{|c|c|c|c|c|c|c|}
\hline Rank & Land use & Places & $N(\%)$ & $\begin{array}{l}\text { Average weekly } \\
\text { visits by individuals }\end{array}$ & $\begin{array}{l}\text { Total weekly visits } \\
\text { by all participants }\end{array}$ & $\begin{array}{l}\text { Travel time } \\
\text { (minute) }\end{array}$ \\
\hline I & Religious institution & Church & $103(63.2)$ & 1.9 & 195 & 13 \\
\hline 2 & Food services & Restaurant, café & $56(34.4)$ & 1.8 & 99 & 13 \\
\hline 3 & $\begin{array}{l}\text { Amusement, sports, or } \\
\text { recreation }\end{array}$ & $\begin{array}{l}\text { Gym, swimming pool, } \\
\text { work out area }\end{array}$ & $47(28.8)$ & 2.6 & 122 & 10 \\
\hline 4 & Private households & $\begin{array}{l}\text { Family, friends, neighbor's } \\
\text { home }\end{array}$ & $22(13.5)$ & 2.6 & 58 & 11 \\
\hline 5 & Retail sales or services & $\begin{array}{l}\text { Shopping mall, } \\
\text { supermarket, } \\
\text { bookstore, hairdresser }\end{array}$ & $16(9.8)$ & 3.0 & 48 & 11 \\
\hline 6 & Educational services & $\begin{array}{l}\text { Community center, } \\
\text { senior center }\end{array}$ & $16(9.8)$ & 1.5 & 25 & 15 \\
\hline 7 & $\begin{array}{l}\text { Associations/nonprofit } \\
\text { organizations }\end{array}$ & Legion, Lions, Rotary club & $8(9.8)$ & 1.4 & 11 & 12 \\
\hline 8 & Unclassified & Study group, social group & $8(4.9)$ & 1.3 & 10 & 13 \\
\hline 9 & $\begin{array}{l}\text { Performing arts or } \\
\text { supporting est. }\end{array}$ & Cinema & $5(3.1)$ & 1.2 & 6 & 9 \\
\hline 10 & $\begin{array}{l}\text { Health and human } \\
\text { services }\end{array}$ & Hospital & $4(2.5)$ & 2.0 & 8 & 10 \\
\hline II & $\begin{array}{l}\text { Natural and other } \\
\text { recreational parks }\end{array}$ & Park, dog park & $2(1.2)$ & 2.0 & 4 & 10 \\
\hline
\end{tabular}

Note: $N$ indicates the number of respondents who indicated the specific place as their third place. The table does not include places, each of which had only one respondent (i.e., retirement communities, hotels, banks, museums, and fishing areas). 
Table 5. Measurement Model.

\begin{tabular}{|c|c|c|c|c|}
\hline Constructs & Items & Loadings & Composite reliability & AVE \\
\hline \multirow[t]{3}{*}{ Social support network } & $\mathrm{cl}$ & 0.778 & 0.844 & 0.644 \\
\hline & c2 & 0.790 & & \\
\hline & c3 & 0.837 & & \\
\hline \multirow[t]{3}{*}{ Loneliness } & c4 & 0.774 & 0.815 & 0.595 \\
\hline & c5 & 0.815 & & \\
\hline & c6 & 0.722 & & \\
\hline \multirow[t]{3}{*}{ Third place } & num & 0.919 & 0.933 & 0.822 \\
\hline & pla & 0.910 & & \\
\hline & tfre & 0.890 & & \\
\hline \multirow{3}{*}{$\begin{array}{l}\text { Perceived neighborhood } \\
\text { accessibility }\end{array}$} & al & 0.884 & 0.891 & 0.731 \\
\hline & a2 & 0.888 & & \\
\hline & a3 & 0.791 & & \\
\hline \multirow{3}{*}{$\begin{array}{l}\text { Neighborhood safety } \\
\text { from crime }\end{array}$} & $\mathrm{crl}$ & 0.881 & 0.898 & 0.746 \\
\hline & $\mathrm{cr} 2$ & 0.884 & & \\
\hline & $\mathrm{cr} 3$ & 0.825 & & \\
\hline \multirow[t]{5}{*}{ Self-efficacy } & sel & 0.768 & 0.904 & 0.653 \\
\hline & se2 & 0.779 & & \\
\hline & se3 & 0.837 & & \\
\hline & se4 & 0.830 & & \\
\hline & se5 & 0.823 & & \\
\hline \multirow[t]{2}{*}{ Mobility frequency } & $\mathrm{mfl}$ & 0.828 & 0.824 & 0.701 \\
\hline & $\mathrm{mf2}$ & 0.846 & & \\
\hline \multirow[t]{2}{*}{ Mobility independence } & $\mathrm{mil}$ & 0.900 & 0.923 & 0.856 \\
\hline & $\mathrm{mi} 2$ & 0.950 & & \\
\hline
\end{tabular}

Note: All values are significant $(p<.00 \mathrm{I})$. AVE $=$ average variance extracted.

model adequate for exploratory purposes, CRs should be equal to or greater than .6 (Chin 1998); for confirmatory purposes, CRs should be equal to or greater than .70 for an adequate model (Henseler, Ringle, and Sarstedt 2012, 269). Table 5 shows that the loadings of all items and CR of the constructs meet the stipulated thresholds.

Third, for convergent validity which tests the relationship among indicators within the same construct that should be highly correlated with each other, the average variance extracted (AVE) was used. AVE should be greater than 0.5 (Bagozzi and Yi 1988; Chin 1998) as well as greater than the cross-loadings, which means that factors should explain at least half the variance of their respective indicators. Table 5 shows that all the AVE values are above threshold of 0.5 .

Fourth, the discriminant validity of the constructs was tested using the criterion of Fornell-Larcker (Fornell and Larcker 1981) and the Heterotrait-Monotrait ratio of correlations (HTMT). As a latent construct should share more variance with its assigned indicators than with any other latent constructs, the square root of the AVE of each latent construct should be higher than the construct's highest correlation with any other latent constructs (Hair et al. 2019). Table 6 presents the correlation matrix of the constructs together with the square root of the AVEs. Each construct meets this requirement. The HTMT is another measure of discriminant validity, which has been recently regarded as outperforming the Fornell-Larcker criterion (Henseler et al. 2015). The HTMT value should be lower than a threshold value such as 0.85 (for conceptually different constructs) and 0.90 (for conceptually similar constructs) to have a discriminant validity (Hair et al. 2019). Table 7 shows that the HTMT is significantly lower than the threshold values, which confirms that discriminant validity exists.

\section{Structural Model}

The structural model was evaluated by collinearity (variance inflation factor [VIF]), variance explained $\left(R^{2}\right)$, the predictive relevance $\left(Q^{2}\right)$, and the significance and relevance of path coefficients. First, the VIF values should be lower than 3 to confirm that collinearity is not a problem; the VIF value above 5 indicates "probable collinearity issues" and VIF between 3 and 5 is indicative of "possible collinearity issues" (Hair et al. 2019). Table 8 shows that collinearity does not exist.

Second, the variance explained $\left(R^{2}\right)$ is a measure of the model's explanatory power. Our model explained 20.3 percent of the variance in social support network and 17.1 percent of the variance in loneliness. The interpretation of $R^{2}$ is largely dependent on disciplines. In the pure science research, $R^{2}$ above 60 percent is usually required, whereas a $R^{2}$ as low as 10 percent is generally accepted for studies in the field of social sciences. 
Table 6. The Fornell-Larcker Discriminant Validity (Correlations for the Constructs and the Square Root of AVE).

\begin{tabular}{|c|c|c|c|c|c|c|c|c|c|c|c|c|c|c|c|c|c|}
\hline & Acc & Age & City & Edu & Event & Lone & Fem & Value & Alone & Mar & Freq & Indep & SE & Safe & SS & Third & Walk \\
\hline Acc & .855 & & & & & & & & & & & & & & & & \\
\hline Age & -.035 & 1.000 & & & & & & & & & & & & & & & \\
\hline City & .061 & -.068 & 1.000 & & & & & & & & & & & & & & \\
\hline Edu & -.041 & .022 & -.128 & 1.000 & & & & & & & & & & & & & \\
\hline Event & .056 & .036 & .047 & .030 & 1.000 & & & & & & & & & & & & \\
\hline Lone & -.051 & .030 & .018 & .049 & .027 & .772 & & & & & & & & & & & \\
\hline Fem & -.047 & .037 & .009 & -.328 & .032 & -.018 & 1.000 & & & & & & & & & & \\
\hline Value & $-.14 \mid$ & -.044 & -.325 & .215 & -.066 & -.046 & -.123 & 1.000 & & & & & & & & & \\
\hline Alone & .019 & .201 & .137 & .012 & .030 & .092 & .199 & -.145 & 1.000 & & & & & & & & \\
\hline Mar & .025 & -.268 & -.124 & .107 & -.088 & -.087 & -.227 & .199 & -.725 & 1.000 & & & & & & & \\
\hline Freq & -.028 & -.173 & -.069 & .120 & -.035 & -.215 & -.051 & .177 & -.175 & .115 & .838 & & & & & & \\
\hline Indep & .056 & -.194 & .010 & .057 & -.063 & -.198 & -.038 & .118 & -.040 & .151 & .344 & .887 & & & & & \\
\hline SE & .026 & -.162 & -.041 & .058 & -.008 & -.299 & -.108 & .108 & -.043 & .019 & .174 & .205 & .808 & & & & \\
\hline Safe & -.059 & .010 & -.174 & .195 & -.073 & -.173 & -.102 & .226 & -.05 I & .032 & .098 & .126 & .100 & .864 & & & \\
\hline SS & $.07 \mid$ & -.024 & -.050 & .133 & .044 & -.377 & .080 & .033 & -.062 & .050 & .072 & .100 & .333 & .124 & .802 & & \\
\hline Third & .127 & -.003 & -.020 & .003 & .144 & -.057 & .001 & .078 & -.011 & .029 & .187 & .094 & .016 & .015 & .153 & .907 & \\
\hline Walk & .512 & .079 & .049 & -.057 & -.005 & -.012 & -.008 & -.272 & .144 & -.132 & -.093 & -.147 & -.080 & -.089 & .046 & -.108 & 1.000 \\
\hline
\end{tabular}

Note: The square root of AVE values are on the diagonal (in bold). Lone $=$ loneliness; Fem $=$ female; Alone $=$ living alone; Mar $=$ married; SE $=$ selfefficacy; SS = social support network.

Table 7. The Heterotrait-Monotrait Ratio of Correlations (HTMT).

\begin{tabular}{|c|c|c|c|c|c|c|c|c|c|c|c|c|c|c|c|c|c|}
\hline & Acc & Age & City & Edu & Event & Lone & Fem & Value & Alone & Mar & Freq & Indep & SE & Safe & SS & Third & Walk \\
\hline \multicolumn{18}{|l|}{ Acc } \\
\hline Age & .040 & & & & & & & & & & & & & & & & \\
\hline City & .088 & .068 & & & & & & & & & & & & & & & \\
\hline Edu & .046 & .022 & .128 & & & & & & & & & & & & & & \\
\hline Event & .063 & .036 & .047 & .030 & & & & & & & & & & & & & \\
\hline Lone & .083 & .063 & .032 & .076 & .045 & & & & & & & & & & & & \\
\hline Fem & .052 & .037 & .009 & .328 & .032 & .096 & & & & & & & & & & & \\
\hline Value & .178 & .044 & .325 & .215 & .066 & .056 & .123 & & & & & & & & & & \\
\hline Alone & .074 & .201 & .137 & .012 & .030 & .122 & .199 & .145 & & & & & & & & & \\
\hline Mar & .091 & .268 & .124 & .107 & .088 & .108 & .227 & 199 & .725 & & & & & & & & \\
\hline Freq & .094 & .226 & .093 & .159 & .083 & .339 & .066 & .232 & .231 & .150 & & & & & & & \\
\hline Indep & .079 & .208 & .015 & .063 & .065 & .237 & .045 & .125 & .047 & .161 & .488 & & & & & & \\
\hline SE & .062 & .176 & .046 & .065 & .028 & .373 & .125 & .118 & .050 & .043 & .245 & .228 & & & & & \\
\hline Safe & .095 & .070 & .190 & .213 & .081 & .222 & .112 & .246 & .055 & .054 & .143 & .142 & .127 & & & & \\
\hline SS & .089 & .087 & .060 & .158 & .050 & .523 & .094 & .063 & .076 & .062 & .113 & .130 & .414 & .160 & & & \\
\hline Third & .143 & .022 & .024 & .043 & .153 & .080 & .011 & .081 & .025 & .032 & .260 & .105 & .079 & .038 & .186 & & \\
\hline Walk & .572 & .079 & .049 & .057 & .005 & .064 & .008 & .272 & .144 & .132 & .120 & .153 & .088 & .096 & .053 & .116 & \\
\hline
\end{tabular}

Note: Lone = loneliness; Fem = female; Alone = living alone; Mar = married; SE = self-efficacy; SS = social support network; SE = self-efficacy; SS = social support network.

Third, the model's predictive validity of the exogenous latent variables was measured by the Stone-Geisser's $Q^{2}$ Test. Values of $Q^{2}$ greater than 0 suggest that the exogenous constructs have predictive relevance for the endogenous construct under consideration, while values below 0 imply a lack of predictive relevance (Chin 1998). All values were above 0 : social support network $\left(Q^{2}=0.10\right)$ and loneliness $\left(Q^{2}=0.06\right)$.
Fourth, the significance and size of path coefficients were calculated using a bootstrapping procedure with 305 cases and five thousand subsamples (Figure 1). Third places positively influenced social support network, but it did not affect loneliness (Hla supported and HIb rejected). Neither objective nor perceived neighborhood accessibility was associated with social support network ( $\mathrm{H} 2 \mathrm{a}$ and $\mathrm{H} 3 \mathrm{a}$ rejected). Similarly, loneliness was not associated with either objective 
Table 8. Inner VIF Values.

\begin{tabular}{lcc}
\hline & Social support network & Loneliness \\
\hline Access to amenities & 1.488 & 1.488 \\
Age & 1.162 & 1.162 \\
City & 1.176 & 1.176 \\
Education & 1.250 & 1.250 \\
Significant life events & 1.057 & 1.057 \\
Female & 1.212 & 1.212 \\
Home value & 1.322 & 1.322 \\
Living alone & 2.335 & 2.335 \\
Married & 2.426 & 2.426 \\
Mobility frequency & 1.283 & 1.283 \\
Mobility independence & 1.279 & 1.279 \\
Self-efficacy & 1.105 & 1.105 \\
Neighborhood safety & 1.121 & 1.121 \\
Third place & 1.129 & 1.129 \\
Walk Score & 1.584 & 1.584 \\
\hline
\end{tabular}

Note: VIF $=$ variance inflation factor.

or perceived neighborhood accessibility ( $H 2 b$ and $H 3 b$ rejected). Neighborhood safety, another dimension of neighborhood walkability, was negatively associated with loneliness; however, it had no association with social support network ( $H 4$ a rejected and H4b supported).

Control variables in the model were based on the correlates of social support and loneliness among the general population as evidenced in previous studies. In our sample of the elderly population, the findings show some similarities and differences. Self-efficacy was found to be the most powerful predictor of both social support and loneliness in later life. Mobility frequency was negatively associated with loneliness; that is, enabling seniors to go outside of home frequently would lead to reduce loneliness. Females tend to have stronger social support network than males in later life. Education was positively associated with social support network. In later life, home property values (a proxy measure for income and wealth), age, marital status, and whether a person lives alone or not did not influence either support network or loneliness.

\section{Discussion and Conclusion}

There has been a long pursuit of examining the role of built environment on social relationships. However, most studies focused on social ties among neighbors or within a specific place (e.g., a restaurant, a club, or a community center). Few studies examined how neighborhood environment and social environment within and beyond a neighborhood influence older adults' overall social support network and loneliness. The findings of this study provide more accurate empirical evidence to the importance of third places for older adults' social health by eliminating the bias existing in previous research through the inclusion of both users and nonusers of third places. Another contribution of this study to the literature on walkability and social health is the study setting. College towns have been so far the least studied context in regard to the investigation of older adults' living environment and well-being despite the growing popularity as a place of retirement in the United States. Our study shed light on the determinants of social health among older adults living in such context.

The most significant contribution of this study is the identification of third places as a significant predictor of older adults' overall social support network in comparison with neighborhood walkability. According to our finding, the subjective dimension of social connectedness (i.e., loneliness) is not affected by either third places or access to amenities; however, the objective dimension of social connectedness (i.e., social support network) is significantly influenced by third places. To develop and strengthen older adults' social support network, creating third places and increasing the access to third places should be given a priority in planning and development.

The importance of retail services on older adults' overall social support and loneliness has been evidenced by the findings of our study. From the popularity ranking of third places among older adults (Table 4), food-related places are the second most used places and other retail places are also ranked high. The most important factor, being consistently found across previous studies on the relationship between built environment and sense of community (or social capital), was the density of retail services rather than mixed-use or the number of destinations within a walking distance (Du Toit et al. 2007; Lund 2003; Wood et al. 2010).

The mechanism how walkability affects social relationship has not been clear among older adults. Often, the focus of discussion seems to be walking behavior per se (i.e., leisure and transportation walking) rather than place-based and place-induced behavior within and beyond a neighborhood. Our findings do not undermine the importance of neighborhood walkability for health, but call for the repositioning of the role of neighborhood walkability on social health. Further studies may need to test the indirect effect of walkability through mediation analysis.

To ensure the well-being of older adults, the development of the settlement for the elderly should be safe from the risk of crime. As shown in the results, the provision of a safe and secure environment may reduce the chances of seniors feeling lonely. It is largely believed that residents tend to develop a stronger sense of community by engaging in activities with other people only if they reside in a safe and secure neighborhood. As such, it could be inferred that neighborhood safety may appear to be one of the most desirable elderly friendly elements for older adults to consider when deciding the ideal place to retire.

Future research should address some limitations of the study. First, this study used a cross-sectional data due to the 


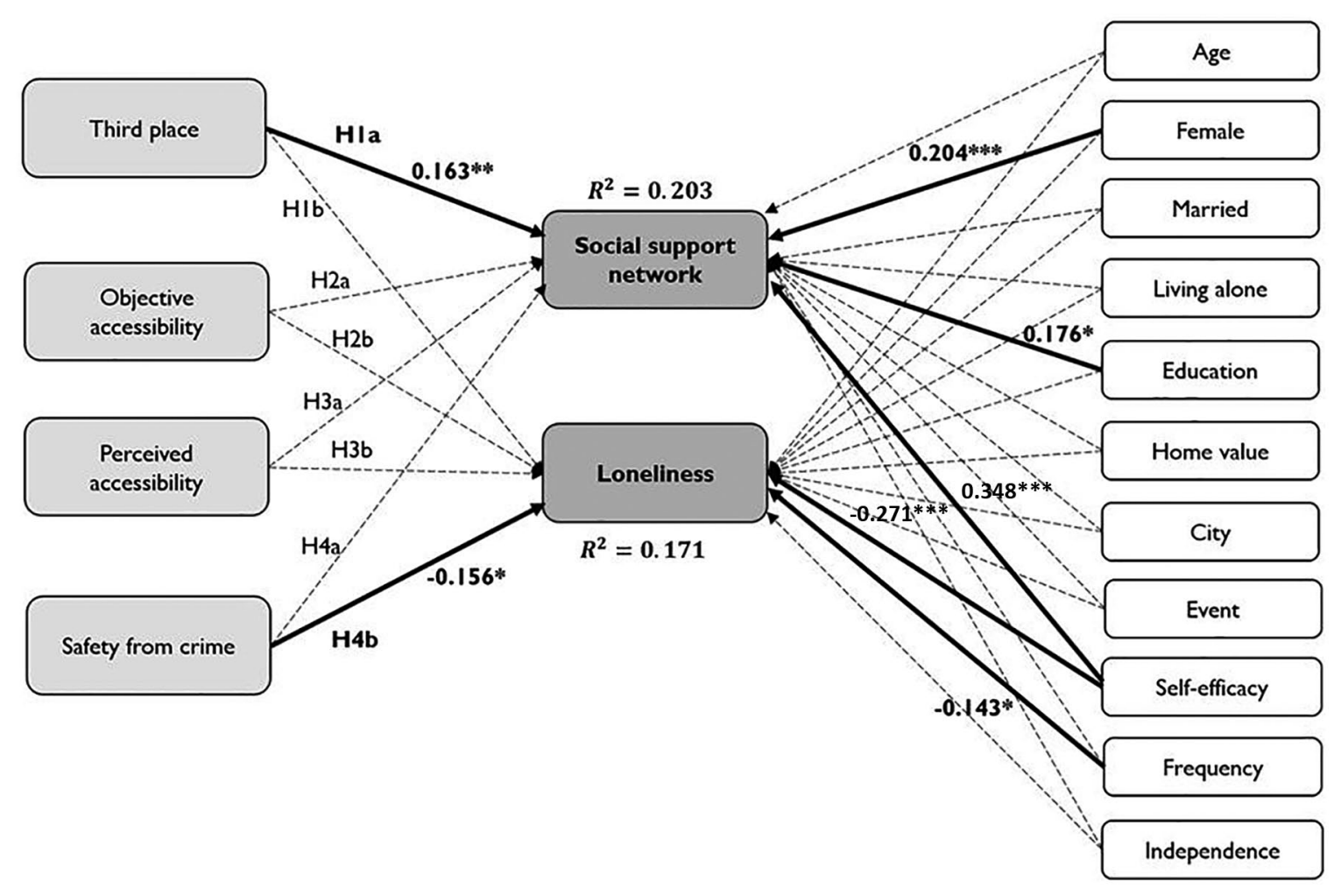

Figure I. Results: Path coefficients with statistical significance.

Note: Dotted lines indicate the statistically insignificant coefficients of structural paths. $*_{p}<.05 . * * p<.01$. *** $p<.001$.

time and resource constraints. Experimental design or time series data would be helpful to validate the causal relationship. Second, our research findings should be taken with a caution when attempting to generalize to different contexts in terms of population size, density, and socioeconomic characteristics. Third, this study did not control for the detailed amount and quality of family support which required adding significant length to the survey questionnaire. Instead, marital and living status were measured as proxy variables. Analysis with controls for detailed family structure and support could produce more accurate information.

Parks and community centers have been considered as the most representative leisure spaces in the United States. Although parks were located within a walking distance or short driving distance from participants' residences, few responded that their third place was a park, which implies that parks may be underused among the elderly. Similarly, senior or community centers have been known as one of the representative leisure spaces for seniors, which provide structured senior programs all year round. Nevertheless, only 4.2 percent of participants used a senior or community center as a third place. Further investigation may be needed to find out the reasons why parks and community or senior centers are being underused with reference to baby boomer's socializing characteristics and leisure preferences.

The challenge that our communities face is how we are going to reshape existing infrastructure to accommodate the needs of the aging population who prefers to age in place. A few practical suggestions can be drawn from our findings. First, map out the provision and qualities of third places which older adults use for socializing. Our findings shown in Table 4 gives an overview on what places are popular among older adults. Second, reshape the existing public spaces or places not highly ranked in terms of popularity to equip with more senior-friendly features. Third, develop and provide various transport and service options to popular third places among older adults.

Quality of life in old age is increasingly related to neighborhood characteristics. Older adults usually make their judgment about neighborhood conditions based on their needs. The extent to which older adults' needs are met by their neighborhood environments indicates how they think of their neighborhood and how it affects their well-being. In this regard, the interaction between older adults and environmental characteristics such as third-place factors and neighborhood safety should be taken into consideration to expand and strengthen social support network and reduce loneliness. 


\section{Acknowledgments}

The authors thank Professors Elise Bright, Scott Shafer, Chanam Lee, and Gerard Kyle, as well as the editor and three anonymous reviewers, for providing general research guidance and helpful comments on a draft.

\section{Declaration of Conflicting Interests}

The author(s) declared no potential conflicts of interest with respect to the research, authorship, and/or publication of this article.

\section{Funding}

The author(s) received no financial support for the research, authorship, and/or publication of this article.

\section{ORCID iD}

Ji Hei Lee (iD https://orcid.org/0000-0003-2968-7582

\section{References}

Alidoust, Sara, Caryl Bosman, and Gordon Holden. 2018. "Planning for Healthy Ageing: How the Use of Third Places Contributes to the Social Health of Older Populations." Ageing \& Society 39 (7): 1459-84.

Allred, Shorna Broussard, and Amy Ross-Davis. 2011. "The Drop-Off and Pick-Up Method: An Approach to Reduce Nonresponse Bias in Natural Resource Surveys." Small-Scale Forestry 10 (3): 305-18.

American Planning Association. 1999. Land-Based Classification Standards. Chicago: American Planning Association.

Bagozzi, Richard P., and Youjae Yi. 1988. "On the Evaluation of Structural Equation Models." Journal of the Academy of Marketing Science 16 (1): 74-94.

Barnes, Lisa L., C. F. Mendes de Leon, Robert S. Wilson, Julia L. Bienias, and Denis A. Evans. 2004. "Social Resources and Cognitive Decline in a Population of Older African Americans and Whites." Neurology 63 (12): 2322-26.

Brooks, Rodney. 2018. "Baby Boomers Are Retiring to College Towns." U.S. News, August 31. https://money.usnews.com/ money/retirement/baby-boomers/articles/2018-08-31/babyboomers-are-retiring-to-college-towns.

Carle, Andrew. 2006. University-Based Retirement Communities: Criteria for success. Institute for the Advancement of Senior Care, September 1. https://www.iadvanceseniorcare.com/ university-based-retirement-communities-criteria-for-success/ (accessed June 1, 2019).

Carle, Andrew. 2019. "Can University Retirement Communities Reverse Aging?" Forbes, April 22. https:/www.forbes.com/ sites/andrewcarle/2019/04/22/can-university-retirement-communities-reverse-aging/\#3791aeab2558.

Cerin, Ester, Brian E. Saelens, James F. Sallis, and Lawrence D. Frank. 2006. "Neighborhood Environment Walkability Scale: Validity and Development of a Short Form." Medicine \& Science in Sports \& Exercise 38 (9): 1682-91.

Chin, Wynne W. 1998. "The Partial Least Squares Approach to Structural Equation Modeling." Modern Methods for Business Research 295 (2): 295-336.

Cisneros, Henry, Margaret Dyer-Chamberlain, and Jane Hickie, eds. 2012. Independent for Life: Homes and Neighborhoods for an Aging America. Austin: University of Texas Press.
Cuba, Lee, and Charles F. Longino Jr. 1991. "Regional Retirement Migration: The Case of Cape Cod." Journal of Gerontology 46 (1): S33-42.

de Jong-Gierveld, Jenny, Theo G. van Tilburg, and Pearl A. Dykstra. 2006. "Loneliness and Social Isolation." In The Cambridge Handbook of Personal Relationships, edited by Daniel Perlman and Anita L. Vangelisti, 485-500. Cambridge: Cambridge University Press.

Douglas, Jackson-Smith, Mallory Dolan, Grant Holyoak, Courtney G. Flint, Carla K. Trentelman, Blake Thomas, and Guizhen Ma. 2016. "Effectiveness of the Drop-Off/Pick-Up Survey Methodology in Different Neighborhood Types." Journal of Rural Social Sciences 31 (3): 35-67.

$\mathrm{Du}$ Toit, Lorinne, Ester Cerin, Evie Leslie, and Neville Owen. 2007. "Does Walking in the Neighbourhood Enhance Local Sociability?" Urban Studies 44 (9): 1677-95.

Farber, Nicholas, Douglas Shinkle, Jana Lynott, Wendy Fox-Grage, and Rodney Harrell. 2011. Aging in Place: A State Survey of Livability Policies and Practices. Washington, DC: AARP Public Policy Institute.

Federal Interagency Forum on Aging-Related Statistics. 2016. Older Americans 2016: Key Indicators of Well-Being. Federal Interagency Forum on Aging-Related Statistics. Washington, DC: U.S. Government Printing Office. https://agingstats.gov/ docs/LatestReport/Older-Americans-2016-Key-Indicators-ofWellBeing.pdf (accessed February 1, 2018).

Fornell, Claes, and David F. Larcker. 1981. "Structural Equation Models with Unobservable Variables and Measurement Error: Algebra and Statistics." Journal of Marketing Research 18 (3): 382-88.

Fratiglioni, Laura, Hui-Xin Wang, Kjerstin Ericsson, Margaret Maytan, and Bengt Winblad. 2000. "Influence of Social Network on Occurrence of Dementia: A Community-Based Longitudinal Study." The Lancet 355 (9212): 1315-19.

Garson, David. 2016. Partial Least Squares (PLS-SEM). Asheboro, NC: Statistical Associates.

Gefen, David, Detmar Straub, and Marie-Claude Boudreau. 2000. "Structural Equation Modeling and Regression: Guidelines for Research Practice." Communications of the Association for Information Systems 4 (1): 7.

Gibler, Karen M., and Paloma Taltavull. 2010. "Using Preferences for International Retiree Housing Market Segmentation." Journal of Property Research 27 (3): 221-37.

Golant, Stephen M. 2015. Aging in the Right Place. Baltimore: Health Professions Press.

Granovetter, Mark. 1983. "The Strength of Weak Ties: A Network Theory Revisited.” Sociological Theory 1 (1): 201-33.

Haas, William H., III, and William J. Serow. 1993. "Amenity Retirement Migration Process: A Model and Preliminary Evidence." The Gerontologist 33 (2): 212-20.

Hair, Joseph F., Christian M. Ringle, and Marko Sarstedt. 2011. "PLS-SEM: Indeed a Silver Bullet." Journal of Marketing Theory and Practice 19 (2): 139-52.

Hair, Joseph F., Jeffrey J. Risher, Marko Sarstedt, and Christian M. Ringle. 2019. "When to Use and How to Report the Results of PLS-SEM.” European Business Review 31 (1): 2-24.

Hanibuchi, Tomoya, Katsunori Kondo, Tomoki Nakaya, Kokoro Shirai, Hiroshi Hirai, and Ichiro Kawachi. 2012. "Does Walkable Mean Sociable? Neighborhood Determinants of Social Capital among Older Adults in Japan." Health \& Place 18 (2): 229-39. 
Havens, Betty, Madelyn Hall, Gina Sylvestre, and Tyler Jivan. 2004. "Social Isolation and Loneliness: Differences between Older Rural and Urban Manitobans." Canadian Journal on Aging/La Revue canadienne du vieillissement 23 (2): 129-40.

Hawthorne, Graeme. 2008. "Perceived Social Isolation in a Community Sample: Its Prevalence and Correlates with Aspects of Peoples' Lives." Social Psychiatry and Psychiatric Epidemiology 43 (2): $140-50$

Henning, Cecilia, and Mats Lieberg. 1996. "Strong Ties or Weak Ties? Neighbourhood Networks in a New Perspective." Scandinavian Housing and Planning Research 13 (1): 3-26.

Henseler, Jörg, Christian M. Ringle, and Marko Sarstedt. 2012. "Using Partial Least Squares Path Modeling in Advertising Research: Basic Concepts and Recent Issues." In Handbook of Research on International Advertising, edited by Shintaro Okazaki, 252-76. Cheltenham: Edward Elgar.

Henseler, Jörg, Christian M. Ringle, and Marko Sarstedt. 2015. "A New Criterion for Assessing Discriminant Validity in Variance-Based Structural Equation Modeling." Journal of the Academy of Marketing Science 43 (1): 115-35.

Hickman, Paul. 2013. "Third Places' and Social Interaction in Deprived Neighbourhoods in Great Britain." Journal of Housing and the Built Environment 28 (2): 221-36.

House, James S., Karl R. Landis, and Debra Umberson. 1988. "Social Relationships and Health." Science 241 (4865): 540-45.

House, James S., Cynthia Robbins, and Helen L. Metzner. 1982. "The Association of Social Relationships and Activities with Mortality: Prospective Evidence from the Tecumseh Community Health Study." American Journal of Epidemiology 116 (1): 123-40.

$\mathrm{Hu}$, Shih-Ming, Cheng-I. Wei, Margaret R. Schlais, and Jung-Mao Yeh. 2008. "The Potential of a College Town as a Retirement Community." Journal of Housing for the Elderly 22 (1-2): 45-65.

Kobayashi, Karen M., Denise Cloutier-Fisher, and Marilyn Roth. 2008. "Making Meaningful Connections: A Profile of Social Isolation and Health among Older Adults in Small Town and Small City, British Columbia." Journal of Aging and Health 21 (2): 374-97.

Krause, Neal. 1993. "Neighborhood Deterioration and Social Isolation in Later Life." The International Journal of Aging and Human Development 36 (1): 9-38.

Kweon, Byoung-Suk, William C. Sullivan, and Angela R. Wiley. 1998. "Green Common Spaces and the Social Integration of Inner-City Older Adults." Environment and Behavior 30 (6): $832-58$

Lester, David, and Bijou Yang. 1992. "3 Social and Economic Correlates of the Elderly Suicide Rate." Suicide and LifeThreatening Behavior 22 (1): 36-47.

Leyden, Kevin M. 2003. "Social Capital and the Built Environment: The Importance of Walkable Neighborhoods." American Journal of Public Health 93 (9): 1546-51.

Lui, Chi-Wai, Jo-Anne Everingham, Jeni Warburton, Michael Cuthill, and Helen Bartlett. 2009. "What Makes a Community Age-Friendly: A Review of International Literature." Australasian Journal on Ageing 28 (3): 116-21.

Lund, Hollie. 2002. "Pedestrian Environments and Sense of Community." Journal of Planning Education and Research 21 (3): 301-12.
Lund, Hollie. 2003. "Testing the Claims of New Urbanism: Local Access, Pedestrian Travel, and Neighboring Behaviors." Journal of the American Planning Association 69 (4): 414-29.

Melevin, Paul T., Don A. Dillman, Rodney K. Baxter, and C. Ellen Lamiman. 1999. "Personal Delivery of Mail Questionnaires for Household Surveys: A Test of Four Retrieval Methods." Journal of Applied Sociology 16 (1): 69-88.

Nicholson, Nicholas R., Jr. 2009. "Social Isolation in Older Adults: An Evolutionary Concept Analysis." Journal of Advanced Nursing 65 (6): 1342-52.

Oldenburg, Ramon, and Dennis Brissett. 1982. "The Third Place." Qualitative Sociology 5 (4): 265-84.

Oldenburg, Ray. 1997. "Our Vanishing Third Places." Planning Commissioners Journal 25 (4): 6-10.

Peel, Claire, Patricia Sawyer Baker, David L. Roth, Cynthia J. Brown, Eric V. Bodner, and Richard M. Allman. 2005. "Assessing Mobility in Older Adults: The UAB Study of Aging Life-Space Assessment.” Physical Therapy 85 (10): 1008-19.

Reinartz, Werner, Michael Haenlein, and Jörg Henseler. 2009. “An Empirical Comparison of the Efficacy of Covariance-Based and Variance-Based SEM.” International Journal of Research in Marketing 26 (4): 332-44.

Rogers, Shannon H., John M. Halstead, Kevin H. Gardner, and Cynthia H. Carlson. 2011. "Examining Walkability and Social Capital as Indicators of Quality of Life at the Municipal and Neighborhood Scales." Applied Research in Quality of Life 6 (2): 201-13.

Rosenbaum, Mark S., James Ward, Beth A. Walker, and Amy L. Ostrom. 2007. "A Cup of Coffee with a Dash of Love an Investigation of Commercial Social Support and Third-Place Attachment." Journal of Service Research 10 (1): 43-59.

Sabin, Edward P. 1993. "Social Relationships and Mortality among the Elderly." Journal of Applied Gerontology 12 (1): 44-60.

Schwarzer, Ralf, and Matthias Jerusalem. 1995. "Generalized Self-Efficacy Scale." In Measures in Health Psychology: A User's Portfolio. Causal and Control Beliefs, edited by John Weinman, Stephen C. Wright, and Marie Johnston, 35-37. Windsor: NFER-Nelson.

Steinbach, Ulrike. 1992. "Social Networks, Institutionalization, and Mortality among Elderly People in the United States." Journal of Gerontology 47 (4): S183-90.

Sugiyama, Takemi, and Catharine Ward Thompson. 2007. "Older People's Health, Outdoor Activity and Supportiveness of Neighbourhood Environments." Landscape and Urban Planning 83 (2-3): 168-75.

Tang, Fengyan, and Yeonjung Lee. 2011. "Social Support Networks and Expectations for Aging in Place and Moving." Research on Aging 33 (4): 444-64.

Thompson, Estina E., and Neal Krause. 1998. "Living Alone and Neighborhood Characteristics as Predictors of Social Support in Late Life." The Journals of Gerontology, Series B: Psychological Sciences \& Social Sciences 53 (6): S354-64.

Walk Score. 2011. "Walk Score Methodology." Walkscore.com, July 15. http://cedeuspubs.geosteiniger.cl/omeka/files/original/ b6fa690993d59007784a7a26804d42be.pdf (accessed February 15, 2016).

Wang, Xingmin. 2016. "Subjective Well-Being Associated with Size of Social Network and Social Support of Elderly." Journal of Health Psychology 21 (6): 1037-42. 
Wenger, G. Clare, and Vanessa Burholt. 2004. "Changes in Levels of Social Isolation and Loneliness among Older People in a Rural Area: A Twenty-Year Longitudinal Study." Canadian Journal on Aging/La Revue canadienne du vieillissement 23 (2): 115-27.

Wilkerson, Amy, Nichole E. Carlson, Irene H. Yen, and Yvonne L. Michael. 2012. "Neighborhood Physical Features and Relationships with Neighbors Does Positive Physical Environment Increase Neighborliness?" Environment and Behavior 44 (5): 595-615.

Wood, Lisa, Lawrence D. Frank, and Billie Giles-Corti. 2010. "Sense of Community and Its Relationship with Walking and
Neighborhood Design.” Social Science \& Medicine 70 (9): 1381-90.

\section{Author Biographies}

Ji Hei Lee is a lecturer of real estate and planning in Henley Business School at the University of Reading Malaysia. Her research interests include active aging, social health, and global urbanism.

Teck Hong Tan is a professor in the School of Economics and Management at Xiamen University Malaysia. His research interests include housing studies and real estate economics. 